\title{
Analysis of the Prehistoric Artifacts from the Pace McDonald Site (41AN51), Anderson County, Texas
}

Timothy K. Perttula

Heritage Research Center, Stephen F. Austin State University

Follow this and additional works at: https://scholarworks.sfasu.edu/ita

Part of the American Material Culture Commons, Archaeological Anthropology Commons, Environmental Studies Commons, Other American Studies Commons, Other Arts and Humanities Commons, Other History of Art, Architecture, and Archaeology Commons, and the United States History Commons

Tell us how this article helped you.

This Article is brought to you for free and open access by the Center for Regional Heritage Research at SFA ScholarWorks. It has been accepted for inclusion in Index of Texas Archaeology: Open Access Gray Literature from the Lone Star State by an authorized editor of SFA ScholarWorks. For more information, please contact cdsscholarworks@sfasu.edu. 


\section{Analysis of the Prehistoric Artifacts from the Pace McDonald Site (41AN51), Anderson County, Texas}

\section{Creative Commons License}

\section{(c) (1) \&}

This work is licensed under a Creative Commons Attribution-NonCommercial 4.0 International License 


\title{
Analysis of the Prehistoric Artifacts from the Pace McDonald Site (41AN51), Anderson County, Texas
}

\author{
Timothy K. Perttula
}

\section{INTRODUCTION}

The Pace McDonald site (4lAN51) is a poorly known prehistoric Caddo mound center on Mound Prairie Creek in Anderson County, Texas, in the upper Neches River Basin (Pearce and Jackson 1933; Newell and Krieger 1949; Story 2000; Thurmond 1978). With the permission of one of the landowners, Mr. Johnny Sanford, the Friends of Northeast Texas Archaeology are planning on initiating an archacological research effort at the site in 2010. The ultimate purpose of this work is to learn more about the native history of this mound center-when it was occupied and used, and by which prehistoric Caddo group-its intra-site spatial organization, and ultimately obtain site-specific archaeological information that can help understand the site's place and role in the Caddo prehistory of this part of East Texas.

It will be a long-term effort to accomplish these tasks. We intend to rely upon both archaeological (i.e., survey, surface collections, systematic shovel testing, and focused hand excavations) and archaeogeophysical disciplines (especially to complete a magnetometer survey of as much as the site as possible, as this has become an important aspect of Caddo archacological investigations, see Lockhart [2007], Walker and Perttula [2008], Walker [2009], and McKinnon [2010]), to gather relevant archaeological information on the location and character of Caddo house features and outdoor activity areas, as well as the associated material culture remains and preserved plant and animal remains.

One key aspect of our work is to understand the characteristics of the Caddo material culture from the Pace McDonald site, since this will have a large bearing on the age of the Caddo occupation, which has been a matter of dispute for some years.
In this article 1 summarize the results and findings of a recent examination of the site's prehistoric artifacts (especially its prehistoric Caddo artifacts) in the collections of the Texas Archeological Rcsearch Laboratory at the University of Texas at Austin (TARL).

\section{SITE SETTING}

The Pace McDonald site is situated on a large and relatively flat upland landform (420-430 feet amsl) immediately north of Mound Prairic Creek, in central Anderson County, Texas, in the East Texas Pineywoods (Diggs et al. 2006). Mound Prairic Creek is a southward- and eastward-flowing tributary to the Neches River; the confluence of these two streams lies about $20 \mathrm{~km}$ to the east of the site. When the site was first visited and recorded in the 1930s, it was in a large cotton field (Pearce and Jackson 1933:2). In more recent years, it is in an improved pasture, and the site is apparently owned by several landowners, including the Texas Historical Commission (see below).

The site is on an expanse of Elrose fine sandy loam, 1-3 percent slopes (Coffee 1975:17 and Sheet 34 ). This is a relatively fertile upland soil that "formed under a pine-hardwood forest in stratified marine and alluvial sediment high in glauconitic sandstone" (Coffee 1975:17 and Table 2). A typical profile of the Elrose fine sandy loam is a $25 \mathrm{~cm}$ thick A-horizon that ranges from reddish-brown to yellowish-red fine sandy loam developed atop a thick (ca. $165 \mathrm{~cm}$ ) Bt horizon composed of red, dark red, yellowish-red, or strong brown sandy clay loam and sandy loam. The underlying $\mathrm{C}$ horizon is a massive red loamy fine sand with an occasional fragment of glauconitic sandstone. 


\section{PREVIOUS INVESTIGATIONS AT THE PACE MCDONALD SITE}

Limited archaeological investigations at the Pace McDonald site since the 1930s indicates that the site covers ca. 11 acres $\left(45,000 \mathrm{~m}^{2}\right)$ of the upland landform adjacent to Mound Prairie Creek. The site has two deliberately constructed prehistoric Caddo earthen mounds, a large and associated habitation area (in- cluding several midden areas) and surface scatters of ceramic and lithic artifacts, and probably at least one associated cemctery area (Figure 1). There are also a number of small depressions, with an average depth of $30-60 \mathrm{~cm}$, visible on the landform that may represent borrow pits for sediments used by the Caddo to build the two earthen mounds. In 1978, the depressions ranged from 6.1-25 $\mathrm{m}$ in diameter (Thurmond 1978).

Archaeologists from the Department of Anthro-

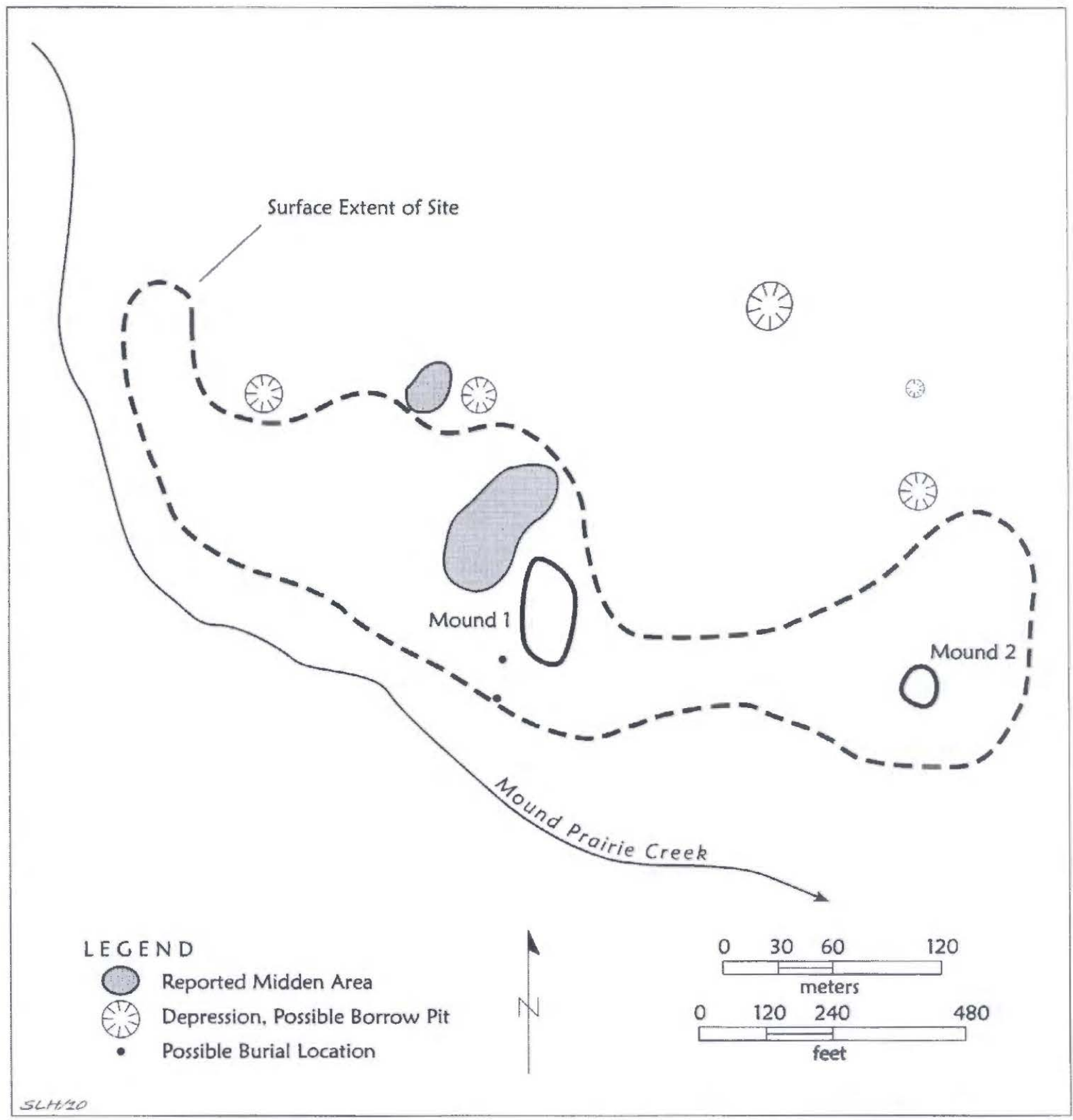

Figure 1. Map of the Pace McDonald site (41AN51), based on a 1978 sketch map by Ulrich Kleinschmidt and Pete Thurmond, and other information in the Texas Archeological Research Laboratory, The University of Texas at Austin files. 
pology at The University of Texas at Austin (UT) conducted surface collections and test excavations at the Pace McDonald (or Royal Place) site in September 1933 (Pearce and Jackson 1933). They noted two mounds, Mound No. 1 and Mound No. 2, spaced about $280 \mathrm{~m}$ apart, in the field, as well as a surface scatter of ceramic and lithic artifacts, cspecially in an area ca. 130-280 m northwest of Mound No. 1 (Pearce and Jackson 1933:6). Mound No. 1 measured $58.2 \mathrm{~m}$ in length (north-south) and $37.5 \mathrm{~m}$ in width, and stood approximately $3 \mathrm{~m}$ in height. Mound No. 2 was $18.3 \mathrm{~m}$ in diameter and stood $1.5 \mathrm{~m}$ in height.

UT archaeologists obtained a collection of chipped and ground stone tools as well as a ceramic pipe from Mr. George W. McIntyre, who was then living on the site and cultivating cotton on the place; he had found most of his artifacts in the area northwest of Mound No. 1. They also collected a ground stone celt ca. $46 \mathrm{~m}$ southeast of Mound No. 1, and a small conch shell ca. $91 \mathrm{~m}$ south of this same mound (Pearce and Jackson 1933:6-7).

Jackson led the exeavations of both mounds. In Mound No. 1, a circular shaft ca. $2.5 \mathrm{~m}$ in diameter was excavated by shovel to a depth of 3.28 $\mathrm{m}$ below the mound surface (bs). From Jackson's descriptions, there were several mound fill zones and perhaps two Caddo house archaeological deposits in the mound. From 0-147 cm bs, there were red $(0-102$ $\mathrm{cm}$ bs) sandy clay loam and yellow $(102-147 \mathrm{~cm} \mathrm{bs})$ clay mound fill or capping zones, with few artifacts; these soils appear to be Bt-horizon sediments that were collected and used to finish the earthen mound. These redistributed sediments capped a $2.5 \mathrm{~cm}$ thick (147.3-149.9 cm bs) sandy red clay, that was described as "fairly hard. Seemed to be a floor level as it extended at the same thickness over the entire dug area. No midden material" (Pearce and Jackson 1933:6). If this was a floor level, the structure associated with it was not used for a lengthy period of time-given the absence of midden deposits-nor was it burned down-given the apparent absence of charcoal on the floor or in the yellow clay above it-before being dismantled and covered over with $147 \mathrm{~cm}$ of mound deposits.

This apparent clay floor to a structure was capped above a reddish-brown sandy loam mound fill zone deposit that extended from 149.9-213 cm bs. This fill zone capped a $49 \mathrm{~cm}$ thick deposit (213$262 \mathrm{~cm}$ bs) of ash, "with charcoal, lumps of red clay and some sand. Potsherd at top of the ashes; no other midden material" (Pearce and Jackson
1933:6). This ash deposit may represent a deliberate accumulation of ash within a confined space, as with the ash mound at the A. C. Saunders site (41AN19, see Jackson 1936; Kleinschmidt 1982), or an accumulation of ash inside a structure that was burned down, as with the ash temple at the Crenshaw site (Schambach 1996). The available archacological information from these early excavations is equivocal, but I suspect this deposit represents ash built up within a structure, along with the dismantled and burned remnants of that structure, mixed in with relatively clean earth.

The ashy deposits rested on a red sandy clay and red clay that extended from $262-328 \mathrm{~cm}$ bs in the excavations. These deposits likely represent the buried Bt horizon of the Elrose fine sandy loam soil under Mound No. 1. If that is the case, then apparently the immediately overlying ash accumulation rested on a prepared surface wherein the A-horizon was scraped away first (a common Caddo practice in and under locations where earthen mounds are to be built), as there are no buried A-horizon (a fine sandy loam) underlying the ash deposit.

A "test hole" of unknown size was excavated by Jackson in Mound No. 2 (Pearce and Jackson 1933:10). These explorations encountered a thick layer of hard-packed ash between $15-56 \mathrm{~cm} \mathrm{bs}$, with gravels and lumps of red clay, but no apparent midden materials. The deposits above that $(0-15 \mathrm{~cm}$ bs) appear to represent the plowed portion of the ash deposit. As with the concentrated ash deposit encountered in Mound No. 1 between 213-262 cm bs, the Mound No. 2 ash zone probably also represents a deliberate accumulation of ash within a confined space, such as a building, or an accumulation of ash inside a structure that was likely dismantled, abandoned, and destroyed. This deposit may represent ash built up within a structure, along with the dismantled (but not burned) remnants of that structure, mixed in with relatively clean earth.

The ash deposit rested atop a $43 \mathrm{~cm}$ thick (56-99 $\mathrm{cm}$ bs) zone of thin lenses $(1-8 \mathrm{~cm})$ of red and yellow clay and sandy soil, probably mound fill zones. Immediately below the ash, however, Pearce and Jackson (1933:10) noted there was a $20 \mathrm{~cm}$ thick (56-76 $\mathrm{cm} \mathrm{bs)}$ red clay zone; this may represent the initial mound platform of Mound No. 2, or the initial mound platform included both the red clay as well as the underlying red sandy lens (76-99 cm bs) if the latter does not represent a buried A-horizon underneath the mound. Excavations continued to $152 \mathrm{~cm} \mathrm{bs}$, and the sediments encountered there 
were described by Pearce and Jackson (1933:10) as a "bluish mixture bearing streaks of yellow, red and gray. The bluish-gray clay-like composition is sticky and has a greasy fecl." This deposit under the mound may represent undisturbed $\mathrm{C}$-horizon deposits.

The next archaeological investigations at the Pace McDonald site did not take place until the late 1970s when Pete Thurmond and Ulrich Kleinschmidt examined the site and took a surface collection, made a pace map of the surface distribution of prehistoric artifacts, the two earthen mounds, and the locations of several possible small borrow pits (sec Thurmond 1978). They noted that the site appeared to be well-prescrved, with little evidence of looting at that time. This work led to the placement of the Pace McDonald site on the National Register of Historic Places a few years later, and the purchasc of one acre containing Mound No. 1 by the Texas Historic Commission in the early 1980s.

Despite the absence of professional archaeological work at the site between 1933-1978, the Pace McDonald site had not been forgotten by East Texas Caddo archacologists. Alex D. Krieger, University of Texas archaeologist, had examined the collections obtained by A. T. Jackson from the site as part of his renowned study of the early Caddo mound center at the George C. Davis site (4ICEI9; Newell and Krieger 1949:196). According to Story (2000:22), Krieger "believed that both the Alto and Frankston foci were represented at the site, but also recognized that it had not been adequately explored."

Following the 1978 surface investigations by Thurmond and Klcinschmidt at the Pace McDonald site, these archaeologists returned to the site in March 1981 to investigate the reported erosion on the back slope of Mound No. 1. While they were there, they obtained a surface collection of artifacts from Mound No. 1 and an area to the northwest of the mound.

In March 1984, Kleinschmidt and Susan Lisk of The University of Texas at Austin inspected the site, noting that there were three pot holes (ca. 0.9 $\mathrm{m}$ in depth) in Mound No. 1, and also noting that a one lane oil top road had been built that crossed the site. This road had cut through a $10 \mathrm{~cm}$ thick midden area ca. $250 \mathrm{~m}$ north of Mound No. 1, in the vicinity of possible borrow pit depression 5 (see Figure 1). A second midden area had been encountered by local collectors and landowner who were building a fence just west of Mound No. 1 (see Figure 1). Finally, Kleinschmidt and Lisk were told by local collectors that several prehistoric Caddo burials had been reportedly discovered and excavated at the site.

More information on the reported burials was provided in 1985 and 1986 by another local amateur archacologist who was familiar with the Pacc McDonald site and other archacological siles along Mound Prairie Creck (TARL files). This amateur archaeologist obtained information that three prehistoric Caddo burials (Burials 1-3) had been excavated not far to the west and south of Mound No. 1 (see Figure 1). These burials were in grave pits approximately $75-90 \mathrm{~cm}$ deep that were oriented east-west or north-south; the human remains were reported to be in a poor preservation condition. The Caddo burials had funcrary offerings, including plain and decorated ceramic jars, bowls, and bottles $(n=9,1$ to 4 vessels per burial) and stone artifacts: a celt, a hammerstone, a pitted stone, and nine round stones (possible polishing stones?). Jan Guy of TARL identificd three of the vessels from Burials 1 and 2 as a Hickory Engraved bottle, a cf. Bowles Creek Plain bowl, and a cl. Weches Fingernail Impressed, var. Alto bowl (see Stokes and Woodring 1981:185-186 and Figures $22 \mathrm{~m}$ and $23 \mathrm{~b}-\mathrm{c}$ ); there were no photographs available of the vessels from Burial 3. Jan Guy (TARL Pace McDonald files, 3/86) suggested that the vessels "date to either the early or Middle Caddoan periods." None of these funerary objects have been properly documented, and it is currently unknown who has control of these artifacts from the Pace McDonald site.

Finally, the last mention in the records at TARL of a prolessional investigation of the Pace McDonald site was a visit by personnel from the Office of the State Archeologist at the Texas Historical Commission in March 1996. They noted that Mound No. 1, owned by the Texas Historical Commission, was badly overgrown.

\section{COLLECTIONS AT THE TEXAS ARCHEOLOGICAL RESEARCH LABORATORY}

The prehistoric artifacts from the Pace McDonald site in the Texas Archeological Research Laboratory collections consists of a variety of ceramic and lithic artifacts. The ceramics include plain and decorated ceramic vessels sherds $(n=975)$ and a ceramic pipe. There are also chipped stone tools in the collection, including dart points $(n=44)$, arrow points $(n=31)$, two bifaces, and a single flake tool, as well as ground stone tools $(n=6)$, and lithic debris 
$(n=11)$. The collection also contains animal bone $(\mathrm{n}=5)$ and a single unmodified marine conch shell.

\section{Ceramic Vessel Sherds}

Combining the various TARL collections obtained from the Pace McDonald site from the early 1930 s to the mid-1980s, including surface collections, the 1933 excavations, and donated collections, the collections from the site amount to a total of 975 ceramic vessel sherds. Approximately $77 \%$ of the vessel sherds are from undecorated vessels or the undecorated portions of decorated vessels; $22.6 \%$ of the sherds, including both fine wares (engraved and red-slipped sherds) and utility wares (wet paste decorations), are decorated (Table 1).

Plain to decorated sherd ratios (P/DR) from numerous Caddo sites in East Texas appear to hold considerable promise as an independent means of establishing the age of Caddo ceramic-bearing components (provided samples of plain and decorated sherds are larger than about 200-300 sherds per site; the Pace McDonald site meets this data threshold). When P/DR ratios from different ceramic assemblages can be linked with absolute ages as established by radiocarbon dating from those assemblages, this should allow further refinements in how P/DR ratios change through time in East Texas Caddo sites. Looking at Early Caddo to Historic Caddo ceramic assemblages in the region through time, ceramic assemblages have lower proportions of undecorated sherds through time and thus a lower P/DR ratio (Perttula 2008a:9, 315-317). Analyzed pre-A.D. 1200 sites ( $n=3$ assemblages) have plain/ decorated sherd ratios that range between 2.97-4.80. Middle Caddo sites (ca. A.D. 1200-1450, $n=7$ ) have ratios that range between 1.30-2.65. In known Late Caddo sites $(\mathrm{n}=11)$ in the Neches, Angelina, and Sabine river basins, by contrast, the P/DR ranges from only $1.30-0.47$. Finally, post-A.D. 1680 Caddo occupations in the Neches-Angelina river basin have $\mathrm{P} / \mathrm{DR}$ ratios that range from $0.20-0.30$. The plain to decorated sherd ratio (P/DR) is a relatively high 3.43 at Pace McDonald, suggesting the ceramic asscmblage may date from pre-A.D. 1200 times; the decorated sherd assemblage, however, suggests a post-A.D. 1200 age (see below).

There are 39 rim sherds in the vessel sherd collection. More than $51 \%$ are from decorated utility ware vessels $(n=20)$; another $38.5 \%$ are from plain vessels $(n=15)$, and only $10.3 \%$ are from fine ware vessels $(n=4$, from both engraved and red-slipped vessels). One bowl or carinated bowl with interior and exterior red-slipped surfaces has a distinetive Redwine mode rim treatment (see Walters 2010:78).

The fine ware sherds from the Pace McDonald site have both red-slipped (40\% of the fine ware sherds), red-slipped and engraved $(2 \%)$, and engraved $(58 \%)$ decorative elements (Table 2 ). The proportion of red-slipped sherds (from bottles and bowls/carinated bowls, especially the latter) is considerable for an upper Neches River basin Caddo site (Perttula 2008b). In East Texas generally, the manufacture and use of red-slipped pottery unembellished with engraved decorations is most commonly seen in Middle Caddo ceramic traditions, whether it be in Caddo sites on the Red River or in parts of the upper Sulphur, Big Cypress, and Sabine River basins. Seventy percent of the red-slipped sherds are slipped on both the cxterior and interior surfaces, while $25 \%$ are slipped only on the exterior surfaces; these latter sherds are from bottles. Sherds from vessels slipped only on the interior vessel surface (probably bowls) are not common (5\%).

There are a wide variety of engraved decorative elements in the Pace McDonald fine ware ccramics (Table 3). Of those that have more than just straight or parallel lines of uncertain orientation, this includes cross-hatched engraved lines; sherds with various kinds of hatched (Figure $2 b, d, f-g, i$, $\mathrm{k}-\mathrm{l}$ ) or cross-hatched (Figure $2 \mathrm{a}, \mathrm{h}$ ) elements. One distinctive bottle sherd has excised pendant triangles and hatched zones and hatched triangles (Figure $2 \mathrm{e})$. Other distinctive engraved sherds in the assemblage include a body sherd with panels filled with opposed diagonal engraved lines (Figure $2 \mathrm{c}$ ) and a rim with vertical and opposed diagonal engraved lines (Figure 2j).

Notably absent in the engraved finc wares at the site are types such as Holly Fine Engraved, Spiro Engraved, or Hickory Engraved (Suhm and Jelks 1962). These fine ware engraved types are considered material culture hallmarks of the Early Caddo period (as well as various decorated utility wares, and the Alto phase (e.g., Story 2000:14) in East Texas. Their absence at the Pacc McDonald site certainly would be indicative of the fact that the Caddo occupation here postdates the Early Caddo period.

Among the Pace McDonald utility ware sherds are several different kinds of decorative methods represented, as well as distinctive decorative elements within each of the larger decorative methods classes (Table 4). These principally include sherds from vessels decorated with incised lines $(43.5 \%$ of 
Table 1. Ceramic Vessel Sherds.

\begin{tabular}{lcc}
\hline Sherd Type & No. & Percent \\
\hline Plain rim & 15 & 1.5 \\
Plain body & 679 & 69.6 \\
Plain base $\quad 61$ & 6.2 \\
$\quad$ Subtotal, Plain sherds & 755 & 77.4 \\
Decorated fine ware & 50 & 5.1 \\
Decorated utility ware & 170 & 17.5 \\
$\quad$ Subtotal, Decorated sherds & 220 & 22.6 \\
\hline Totals & 975 & 100.0 \\
\hline
\end{tabular}

punctated, but more likely had incised decorative elements (cf. Dunkin Incised or Weches Fingernail Impressed), typical of Caddo utility wares that have different rim and body decorations.

The incised-punctated sherds at the Pace McDonald site, including all of the incised-punctated rim sherds and the one vessel section (see Table 4), have diagonal or opposed diagonal incised lines with associated triangular zoncs filled with tool punctations or cane punctations (see Figure $3 a-b, d)$. These utility wares are likely from Canton Incised and Pennington PunctatedIncised vessels. Other sherds have a zone of punctations adjacent to simple geometric

the utility wares), sherds with punctated elements $(42.9 \%)$, and sherds from vessels decorated with incised-punctated clements (7.1\%). Minor decorative methods documented in the site's utility wares are brushed $(2.9 \%)$, pinched $(2.4 \%)$, and appliqued $(1.2 \%)$ categories (Table 4 ).

Among the incised utility wares, the most popular decorative elements include widely-spaced crosshatched lines (likely either from Canton Incised or Dunkin Incised vessels), opposed incised lines (Figure 3h, also probably from Canton Incised or Dunkin Incised vessels), parallel or straight incised lines of uncertain orientation (possibly body decorative treatments), and diagonal or horizontal incised lines on the vessel rim. These incised sherds may be from Davis Incised, Dunkin Incised, or Canton Incised vessels, or from other Caddo ceramic types with incised elements that have not been identified to date in the region. Most of the incised rim sherds in the assemblage are from cross-hatched incised vessels (see Table 4).

The punctated sherds from the site are comprised of a mixture of tool $55 \%$ of the punctated sherds, including tool punctations arranged in linear rows), fingernail $(33 \%)$, large and small circular $(11 \%)$, and cane $(1 \%)$ punctated elements (see Table 4 ). The only punctated rim sherds $(n=3)$ have rows of tool punctations on them. The majority of punctated sherds are body sherds, indicating that the bodics of many utility ware vessels are decorated with punctations; the decoration on the rims of these vessels was probably not incised elements (see Figure 3c-f), with the punctated elements apparently limited to the body of the vessel and the incised elements restricted to the rim. One sherd has a narrow incised zone or band filled with cane punctations (see Figure $3 \mathrm{c}$ ); this decoraPunctated-Incised vessels (see Suhm and Jclks 1962:Plate 61d-e).

Table 2. Decorated sherds from the Pace McDonald site.

\begin{tabular}{lcc}
\hline Decorative Method & No. & Percent \\
\hline Fine Ware & & \\
Engraved & 29 & 13.2 \\
Engraved-red slipped & 1 & 0.5 \\
Red-slipped & 20 & 9.1 \\
& & \\
Utility Ware & 74 & 33.6 \\
Incised & 37 & 16.8 \\
Tool punctated & 24 & 10.9 \\
Fingernail punctated & 12 & $5.5 *$ \\
Incised-punctated & 8 & 3.6 \\
Circular punctated & 5 & 2.3 \\
Brushed & 4 & 1.8 \\
Pinched & 3 & 1.3 \\
Linear punctated & 1 & 0.5 \\
Cane punctated & 1 & 0.5 \\
Appliqued & 1 & 0.5 \\
Appliqued-punctated & 220 & 100.0 \\
\hline Totals &
\end{tabular}

*There is also one vessel section comprised of 12 body sherds and one rim sherd; it is not included in the total number of decorated sherds. tive element has been documented on Pennington 
Table 3. Decorative elements in the fine ware sherds.

\begin{tabular}{lcc}
\hline Decorative elements & No. & Percent \\
\hline Interior red slip & 1 & 2.0 \\
Interior/exterior red slip* & 14 & 28.0 \\
Exterior red slip** & 5 & 10.0 \\
& & \\
Straight engraved line & 5 & 10.0 \\
Straight engraved line and hatched pendant triangle & 1 & 2.0 \\
Parallel engraved lines, widely-spaced & 1 & 2.0 \\
Parallel engraved lines, excised pendant & & \\
triangles, hatched band, and hatched triangle** & 1 & 2.0 \\
Horizontal and diagonal lines & 1 & 2.0 \\
Horizontal line and diagonal hatched triangle & 1 & 2.0 \\
Horizontal line and cross-hatched engraved pendant triangle+ & 1 & 2.0 \\
Opposed engraved lines & 1 & 2.0 \\
Vertical and diagonal opposed lines+ & 1 & 2.0 \\
Hatched curvilinear zone & 1 & 2.0 \\
Hatched oval++ & 1 & 2.0 \\
Hatched straight zone & 1 & 2.0 \\
Hatched triangular zone & 2 & 4.0 \\
Engraved panel with diagonal and widely-spaced lines** & 1 & 2.0 \\
Opposed engraved panels** & 1 & 2.0 \\
Cross-hatched engraved lines & 4 & 8.0 \\
Cross-hatched engraved triangles** & 1 & 2.0 \\
Curvilinear engraved line & 1 & 2.0 \\
Curvilinear engraved lines and hatched triangles** & 1 & 2.0 \\
Curvilinear engraved line and ext. red slip** & 1 & 2.0 \\
Curvilinear and parallel engraved lines & 1 & 2.0 \\
Oval engraved lines & 1 & 2.0 \\
\hline Total & 50 & 100.0 \\
\hline tiches & & \\
\hline & 1 & \\
\hline
\end{tabular}

*includes one Redwine mode rim; **bottle sherds; +=rim sherd; ++=lip notched rim

There is one Weches Fingernail Impressed, var. Weches body sherd (see Stokes and Woodring 1981 ) in the assemblage. This particular sherd has crescent-shaped punctated elements above or adjacent to a single straight incised linc.

A distinctive characteristic of the Pace McDonald utility wares is the occurrence of sherds from brushed, pinched, and appliqued jars, but only in low frequencies (see Table 4). These three categories of decorated utility wares together comprise only $6.5 \%$ of the assemblage. They apparently represent different means of rim and/or body decoration on jars, with parallel (likely vertical) brushing on jar bodies; vertical appliqued fillets on jar bodies; and vertical pinched rows on both the rim and body of jars. The typological identification of the brushed and appliqued wares is currently uncertain. The pinched jars may be from Killough Pinched vessels (see Suhm and Jelks 1962:Plate 46f).

The very low frequency of brushed pottery at the Pace McDonald site would seem to be indicative of the lact that the site was not used in the Frankston phase (ca. A.D. 1400-1650), since brushed utility wares like Bullard Brushed account for at least $50-80 \%$ of all the decorated sherds in upper Neches River basin Frankston phase assemblages (Perttula 2008b:Table 6-38). By comparison to the Pace McDonald site, and its less than $3 \%$ brushed sherds in the decorated sherd 


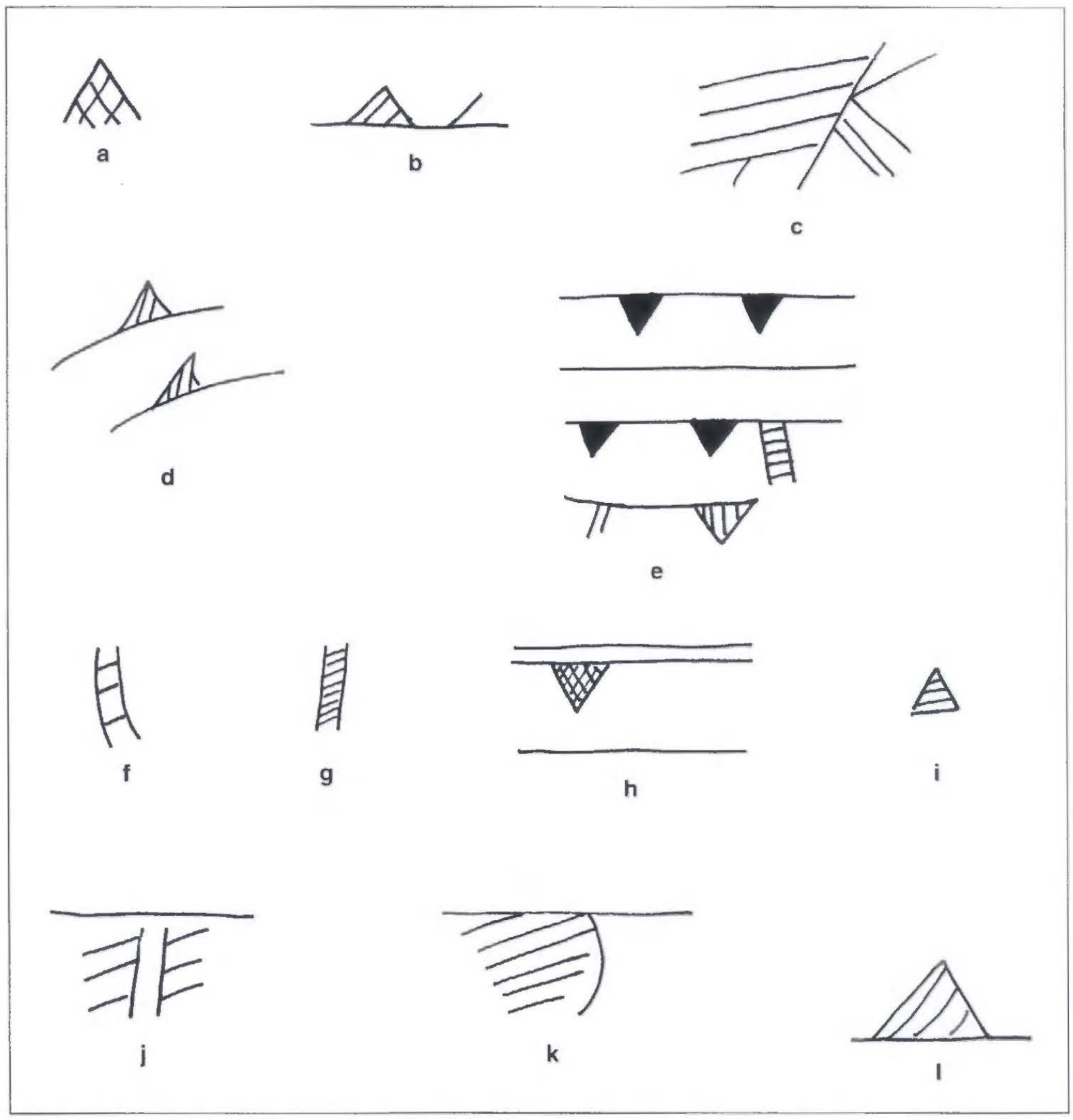

Figure 2. Selected decorative elements on engraved fine ware sherds from the Pace McDonald site: a, cross-hatched triangle; b, straight line and hatched pendant triangle; $c$, panels with opposed diagonal lines; d, curvilinear line with hatched triangles; e, parallel lines, excised triangles, hatched band, and hatched triangles; $\mathrm{f}$, hatched curvilinear zone; $\mathrm{g}$, hatched straight zone; $h$, horizontal lines and cross-hatched pendant triangle; $i$, hatched triangle; $j$, vertical and diagonal opposed; $\mathbf{k}$, hatched oval; $\mathbf{l}$, horizontal line and diagonal hatched triangle.

assemblage, the well-dated A.D. 1320-1400 Middle Caddo component at the Lang Pasture site (41 AN38), brushed sherds comprise $26 \%$ of the utility wares, but by the early 15 th century A.D., "Caddo potters in the upper Neches River basin began to manufacture considerable numbers of jars with brushed vessel bodies and rims" (Perttula 2008b:6-247).
There are also three perforated body and base sherds in the Pace McDonald collection. These likely represent spindle whorls, are disk-shaped sherds (usually base sherds) that have a central perforation or hole drilled in them. The spindle whorl would have been affixed on a spindle to help maintain its rotary motion during spinning activities. The 
Table 4. Decorative elements in the utility ware sherds.

\begin{tabular}{|c|c|c|}
\hline Decorative methods and elements & No. & Percent \\
\hline Appliqued fillets & 1 & 0.6 \\
\hline Appliqued fillets and tool punctated rows & 1 & 0.6 \\
\hline Subtotal, appliqued & 2 & 1.2 \\
\hline Brushed, parallel & 5 & 2.9 \\
\hline Subtotal, brushed & 5 & 2.9 \\
\hline Cross-hatched incised linest++ & 22 & 12.9 \\
\hline Diagonal incised lines* & 4 & 2.4 \\
\hline Dunkin Incised & 1 & 0.6 \\
\hline Horizontal incised lines* & 2 & 1.2 \\
\hline Incised zone & 2 & 1.2 \\
\hline Opposed incised lines & 15 & 8.8 \\
\hline Parallel incised lines & 19 & 11.2 \\
\hline Straight incised line & 9 & 5.3 \\
\hline Subtotal, incised & 74 & 43.5 \\
\hline Vertical pinched ridgest & 4 & 2.4 \\
\hline Subtotal, pinched & 4 & 2.4 \\
\hline Cane punctated & 1 & 0.6 \\
\hline Circular punctated, large & 6 & 3.5 \\
\hline Circular punctated, small & 2 & 1.2 \\
\hline Fingernail punctated rows & 24 & 14.1 \\
\hline Linear punctated rows & 3 & 1.8 \\
\hline Tool punctated rowst+ & 36 & 21.2 \\
\hline Tool punctated, single & 1 & 0.6 \\
\hline Subtotal, punctated & 73 & 42.9 \\
\hline Diagonal incised lines and cane punctated* filled triangles & 2 & 1.2 \\
\hline Diagonal incised line above tool & 1 & 0.6 \\
\hline Horizontal incised line above tool punctated zone & 1 & 0.6 \\
\hline Horizontal incised line above fingernail punctates (on body) & 1 & 0.6 \\
\hline Incised zone filled with cane punctates & 1 & 0.6 \\
\hline Opposed incised lines and tool punctated zone & 1 & 0.6 \\
\hline $\begin{array}{l}\text { Opposed diagonal incised lines and } \\
\text { tool punctated-filled triangles }\end{array}$ & $2^{* *}$ & 1.2 \\
\hline $\begin{array}{l}\text { Straight incised line adjacent to zone } \\
\text { of small circular punctates }\end{array}$ & 2 & 1.2 \\
\hline Weches Fingernail Impressed, var. Weches & 1 & 0.6 \\
\hline Subtotal, incised-punctated & 12 & 7.1 \\
\hline Totals & 170 & 100.0 \\
\hline
\end{tabular}

*all rim sherds; **one rim sherd, also includes a vessel section of 13 conjoined rim and body sherds; +includes one rim sherd; ++includes three rims; +++includes six rims 


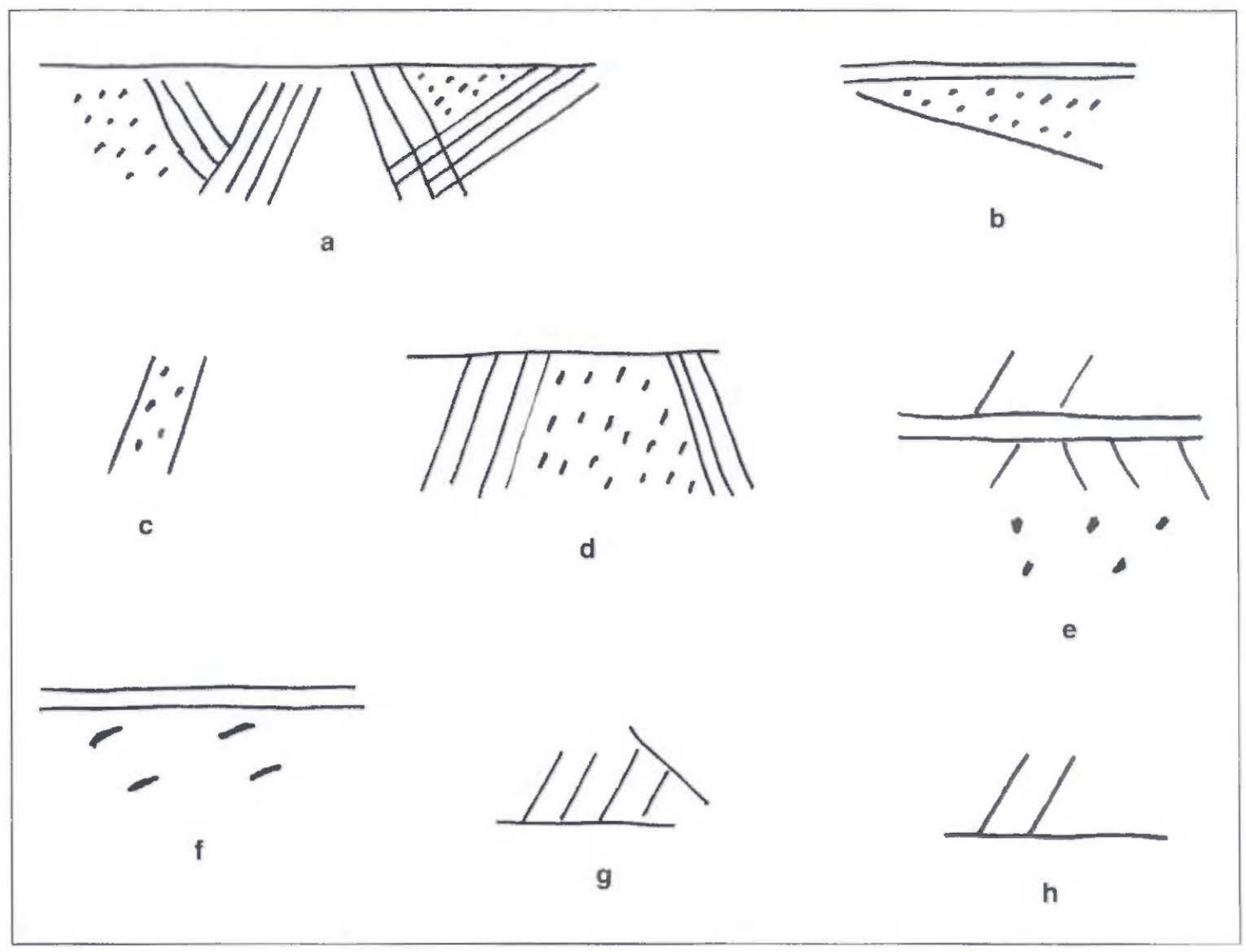

Figure 3. Selected decorative elements on utility ware sherds from the Pace McDonald site: a, opposed diagonal incised lines and tool punctated-filled triangles (Vessel Section); b, horizontal and diagonal incised lines and cane punctatedfilled triangles; $c$, incised zone filled with cane punctates; d, opposed diagonal incised lines and tool punctated-filled triangles; e, opposed incised lines above a tool punctated zone; $f$, horizontal incised lines above fingernail punctates (on the vessel body); $g$, opposed incised (hatched triangle); $h$, opposed incised.

presence of spindle whorls at the Pace McDonald site suggests that Caddo women were processing fibcrs to produce textiles (cf. Alt 1999). Materials that could have been used include animal hair and various vegetable fibers, among them hemp, slippery elm, mulberry, milkweed, and nettlc, as well as the bark of trees.

A detailed analysis of technological attributes of the Pace McDonald ceramic sherds was not conducted for this project, due primarily to time constraints and the inability to examine the sherd cores in any detail (i.e., by removing a small bit of the sherd to examine a freshly broken profile of the core). Nevertheless, it was possible to observe that the vast majority of ceramic vessel sherds from the site are from vessels tempered with grog (i.e., fired and crushed clay), occasionally in association with other tempers. This is the principal prehistoric Caddo ceramic practice in the upper Neches River vallcy (see Perttula 2008b:Figure 6-70). More than $14 \%$ of the sherds do have crushed and burned bone temper added to the clay paste (Table 5). Proportionally, bone temper is used most frequently in plain wares and utility wares.

\section{Ceramic Pipe}

Ceramic pipes and pipe sherds are common artifacts found in upper Neches River basin Caddo sitcs, especially those sites occupied after ca. A.D. 1400 (Gilmore 1974; Jackson 1933, 1936; Kleinschmidt 1982). Not too surprisingly then, a complete, but undecorated, L-shaped (i.e., L-shaped angle between the bowl and the stem) elbow pipe 
Table 5. Use of bone temper in the Pace McDonald Caddo ceramic sherds.

\begin{tabular}{lrrrr}
\hline Ware & No. & Percent & $\begin{array}{l}\text { No. with } \\
\text { bone temper }\end{array}$ & Percent \\
\hline Plain Ware & 755 & 77.4 & 114 & 80.0 \\
Fine ware & 50 & 5.1 & 4 & 2.8 \\
Utility ware & 170 & 17.5 & 24 & 16.9 \\
\hline Totals & 975 & 100.0 & 142 & 14.5 \\
\hline
\end{tabular}

was in the collections from the Pace McDonald site (Figure 4). The pipe is grog-tempered, and has been burnished on the exterior surface. It is $34.6 \mathrm{~mm}$ in height, and has a $55.6 \mathrm{~mm}$ stem length. The bowl orifice diameter is $23.7 \mathrm{~mm}$, and the bowl itself is $3.7 \mathrm{~mm}$ thick. Along the stem, the exterior orifice diameter is $13.9 \mathrm{~mm}$; the interior orifice diameter is $7.7 \mathrm{~mm}$; and the stem is $3.1 \mathrm{~mm}$ thick.

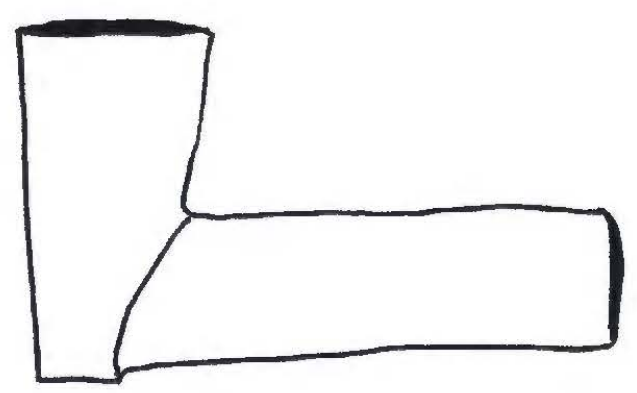

Figure 4. L-shaped elbow pipe from the Pace McDonald site.

Elbow pipes are a style of ceramic pipe manufacture that began to be popular after ca. A.D. 1350 in East Texas and elsewhere in the Caddo area (see Hoffman 1967; Rogers and Perttula 2004; Perttula $2008 \mathrm{~b}$ ), but are virtually the exclusive form of clay pipe made by the Caddo from the 15th century A.D. on. An examination of the clay elbow pipes from mortuary contexts in the upper Neches River basin (see Perttula 2008b), from cemeteries of known age, indicates that the earliest elbow pipes (Var. A) are plain L-shaped forms. Radiocarbon and thermoluminescence dates on sherds indicate that L-shaped pipes at the Lang Pasture site (4 IAN38) date in the 14th century A.D., from ca. A.D. 1320-1400. In other upper Neches River basin sites of known age (i.e., dating to the Frankston phase, subphase 1-3, and the Allen phase), Var. A pipes are restricted to pre-A.D. 1480 components.

\section{Arrow Points}

The arrow points in the TARL collection at the Pace McDonald site are dominated by parallelstemmed Alba points (as well as a single possible Alba point preform). These account for $55 \%$ of the arrow points (Table 6). Relatively common are contracting stem Perdiz arrow points (23\%) and expanding stem and flaring barb Catahoula points (10\%).

The earliest arrow point form at the Pace McDonald site is probably the Catahoula type. This point is considered diagnostic of late Woodland (ca. A.D. 700-800+) components in the East Texas and Southeast Texas regions (Shafer and Walters 2010). Alba points, on the other hand, are generally considered Formative to Early Caddo period (ca. A.D. 800-1200) arrow points, although because they are diagnostic of the Alto phase (Story 2000), they may date from as long a period of manufacture and use as ca. A.D. 850-1300. They are particularly well-represented at the George C. Davis site on the Neches River (Newell and Krieger 1949:161 and Figure 56a-h), where they are considered the only "resident type."

The later (post-ca. A.D. 1200-1300) arrow points at the Pace McDonald site are dominated by Perdiz points. Perdiz points have been found in a number of East Texas Caddo sites that date from the 13th to the 17th century A.D., but as of yet, unfortunately, no temporally distinctive varieties have been defined within this broad span of time that would permit a more definitive conclusion as to the age of this prehistoric occupation at the site.

The arrow points from the Pace McDonald site are predominantly manufactured from non-local cherts that are apparently from the Edwards Plateau 
Table 6. Arrow points from the Pace McDonald site.

\begin{tabular}{lccccc}
\hline Type & \multicolumn{2}{c}{ Lithic raw Materials } & & \\
& $\begin{array}{c}\text { Non-local } \\
\text { chert }\end{array}$ & $\begin{array}{c}\text { Local } \\
\text { chert }\end{array}$ & Quartzite & $\begin{array}{c}\text { Petrified } \\
\text { wood }\end{array}$ & $\mathrm{N}$ \\
\hline $\begin{array}{l}\text { Alba } \\
\text { Possible Alba } \\
\text { preform }\end{array}$ & 13 & 1 & 2 & - & 16 \\
$\begin{array}{l}\text { Catahoula } \\
\text { Perdiz }\end{array}$ & 1 & - & - & - & 1 \\
Unidentified & 6 & - & 2 & - & 3 \\
\hline Totals & 3 & - & - & 1 & 7 \\
\hline
\end{tabular}

region of Central Tcxas, or from Brazos and Trinity River stream gravels (see Table 6); $74 \%$ of the identifiable points are made from thesc materials. The Caddo knappers that lived at the site clearly had a broad range of lithic raw materials to draw upon, as $82 \%$ of the Alba points and preforms are made from non-local chert, and $86 \%$ of the Perdiz points were made from this same suite of non-local cherts. The early Catahoula stemmed arrow points were made exclusively of petrified wood and quartzite.

\section{Dart Points}

There are 44 dart points in the TARL collections from the Pace McDonald sitc (Table 7). The most common type is the contracting stem Gary, which accounts for $36 \%$ of all the dart points from the site. Based on the shape of the dart points, particularly their basal and stem forms, and the identification of specific dart point types with known or estimated temporal limits (e.g., Story 1990; Turner and Hester

Table 7. Dart points from the Pace McDonald site.

\begin{tabular}{|c|c|c|c|c|c|}
\hline \multirow[t]{2}{*}{ Type } & \multicolumn{3}{|c|}{ Lithic raw Materials } & \multirow[b]{2}{*}{$\begin{array}{c}\text { Petrified } \\
\text { wood }\end{array}$} & \multirow[b]{2}{*}{$\mathrm{N}$} \\
\hline & $\begin{array}{l}\text { Non-local } \\
\text { chert }\end{array}$ & $\begin{array}{l}\text { Local } \\
\text { chert }\end{array}$ & Quartzite & & \\
\hline Gary & 8 & 1 & 5 & 2 & 16 \\
\hline Kent & 3 & - & - & - & 3 \\
\hline Godley-like & 1 & - & 1 & - & 2 \\
\hline Palmillas & 2 & - & - & - & 2 \\
\hline Williams & 1 & - & - & - & 1 \\
\hline Dawson & 1 & - & - & - & 1 \\
\hline Straight stem and flat base & 9 & 1 & 1 & 2 & 13 \\
\hline Expanding stem & 1 & - & - & - & 1 \\
\hline Expanding/narrow stem and flat base & 2 & - & - & - & 2 \\
\hline Expanding stem with concave base & 1 & - & - & - & 1 \\
\hline Expanding to straight stem & 1 & - & - & - & 1 \\
\hline Wells & 1 & - & - & - & 1 \\
\hline Totals & 31 & 2 & 7 & 4 & 44 \\
\hline
\end{tabular}


1999), the dart points from the site were made and used in Middle Archaic (ca. 6000-3000 B.C.), Late Archaic (ca. 3000-500 B.C.), and Woodland period (ca. 500 B.C. to A.D. 800 ) times, primarily the latter.

The dart points from the Pace McDonald site can be grouped into temporal periods, including Woodland, Late Archaic, and Middle Archaic (Table 8 ). The usefulness of these groupings should be evaluated with the proviso that the majority of dart point types that occur in East Texas are not yet welldated by secure archaeological association with a series of calibrated radiocarbon dates from features or single component archaeological deposits, but the estimated temporal periods to which the dart points from the Pace McDonald site are assigned is the product of a few calibrated dates as well as extrapolations with better dated temporal sequences in the western Gulf Coastal Plain, Central Texas, the Ouachita Mountains, and the Ozark Highlands (cf.
Schambach 1982; Story 1990; Trubitt 2009; Turner and Hester 1999). Nevertheless, the groupings follow rather closely the artifact sequences for stone tools postulated by Story (1990:Figures 32 and 33) in her synthesis of the archaeology of the East Texas portion of the Gulf Coastal Plain.

A simple comparison of the number of dart points from the site that fall into each of these periods make evident that Woodland period dart points are by far the most abundant $(52.3 \%)$, particularly the Gary $(n=16)$, Kent $(n=3)$, and Godley $(n=2)$ types. Late Archaic dart points comprise another $40.9 \%$ of the recovered points; these include primarily parallel stemmed and flat-based projectile point forms, expanding stem points with a narrow stem and a flat base, as well as one Williams point. Middle Archaic points include one Dawson and one possible Wells specimens, along with an expanding stem form with a concave base (see Table 8).

Table 8. Summary of dart points by period from the Pace McDonald site, including the percent of dart points made from non-local cherts.

\begin{tabular}{lccc}
\hline Type and Period & No. & Percent & $\begin{array}{l}\text { Percent of } \\
\text { non-local chert }\end{array}$ \\
\hline Woodland & 16 & & \\
$\begin{array}{l}\text { Gary } \\
\text { Kent }\end{array}$ & 3 & 36.4 & 50.0 \\
Godley & 2 & 6.8 & 100.0 \\
cf. Palmillas & 2 & 4.5 & 50.0 \\
Sub-total & 23 & 4.5 & 100.0 \\
& & 52.3 & 60.9 \\
Late Archaic & 13 & & \\
parallel stemmed & 1 & 29.5 & 69.2 \\
Williams & 4 & 2.3 & 100.0 \\
expanding stemmed & 18 & 9.1 & 100.0 \\
Sub-total & & 40.9 & 77.8 \\
Middle Archaic & 1 & & \\
Dawson & 1 & 2.3 & 100.0 \\
cf. Wells* & 1 & 2.3 & 100.0 \\
expanding stem, concave base & 3 & 2.3 & 100.0 \\
Sub-total & 44 & 6.8 & 100.0 \\
\hline Totals & & 100.0 & 70.5 \\
\hline a & 1 & &
\end{tabular}

*no edge grinding 
Several different kinds of lithic raw materials were used in the manufacture of the dart points that ended up discarded at the Pace McDonald site, including a variety of cherts (most of non-local origin); petrified wood; and quartzite. $1 \mathrm{t}$ is clear that non-local chert raw materials were principally used in dart point manufacture during all temporal pcriods of occupation at the site, especially during the Middle and Late Archaic pcriods (see Table 8). Local cherts, quartzite, and petrified wood gradually became more important for dart point manufacture during and after the Late Archaic period, while the use of cherts diminished from $100-77.8 \%$ in the Middle and Late Archaic periods to $60.9 \%$ in the Woodland period.

These trends in the use of lithic raw materials, particularly the non-local cherts that most likely were from gravels that originated from source areas to the west in Central Texas and the Edwards Plateau, suggest that the aboriginal populations that utilized the Mound Prairie Creek area prior to ca. 1200 years ago had access to a wide range of non-local lithic raw materials. This is probably because they were relatively mobile foraging populations that ranged west into the Trinity and Brazos River valleys-where high quality cherts could be obtained from gravel sources-and where they collected these high-quality lithic resources during the course of their settlement and foraging forays. Locally available lithic raw materials became more important as sources of chipped stone tools during the Woodland period. These later groups that used the Pace McDonald site likely had a more territoriallyconfined settlement/foraging area in the East Texas Pineywoods, although certainly there were contacts between Pineywoods Woodland groups and peoples living in areas with high quality chert raw materials that led to the continued and extensive acquisition of non-local chipped stone for tool manufacture and use.

\section{Bifaces}

Both of the two large bifaces in the collection are made from a non-local chert. These bifaces are probably discarded fragments from the attempted manufacture of bifacially chipped dart points.

\section{Flake Tool}

A single flake tool with unilateral use wear is in the Pace McDonald collection. This expedient tool was made from a non-local (Edwards Plateau?) dark gray chert.

\section{Ground Stone Tools}

The ground stone tools in the collection are a disparate lot, with a grooved axe, a polished stone, a mano, and three celts (Table 9); the mano and polished stone are made from locally available lithic raw materials. The grooved axe probably represents a Middle to Late Archaic use of the site, as those are the time periods when this tool type was predominantly used by East Texas prehistoric peoples (cl. Turner 2006). The axc is made from a grayish-black diorite or tuff from a Ouachita Mountains source area, and has been broken above the groove. It is $60.4 \mathrm{~mm}$ wide at the groove, $69.7 \mathrm{~mm}$ from the groove to the bit, $38.2 \mathrm{~mm}$ wide, and the bit width is $65.7 \mathrm{~mm}$.

The cobble-sized mano has been ground smooth on both surfaces from use on a metate or grinding slab. The quartzite polished stone was probably used to polish and finish ceramic vessels made at the site; it is $46.2 \mathrm{~mm}$ in length, $32.3 \mathrm{~mm}$ in width, and 12.2

Table 9. Ground stone tools in the Pace McDonald collection.

\begin{tabular}{lccc}
\hline Tool type & $\begin{array}{c}\text { Ouachita Mountains } \\
\text { raw material source }\end{array}$ & Quartzite & $\begin{array}{c}\text { Ferruginous } \\
\text { sandstone }\end{array}$ \\
\hline Celt & 3 & - & - \\
Grooved axe & 1 & - & - \\
Mano & - & 1 & - \\
Polished stone & - & 1 & 1 \\
\hline Totals & 4 & 1 & - \\
\hline
\end{tabular}


$\mathrm{mm}$ thick. The temporal association of these tools is unknown, but the use of such tools would not be unexpected in prehistoric Caddo times.

The three celts are associated with the prehistoric Caddo occupation of the Pace McDonald site. They are made on Ouachita Mountains raw materials, including greenish-gray siliceous shale, tuff or diorite, or graywacke. The tools are completely polished on the body and bit, with either flat $(n=2)$ or rounded $(n=1)$ poll ends. Th celts range in length from 80.3-206.4 mm; width ranges are 37.2-81.7 $\mathrm{mm}$; thickness ranges are $32.2-51.4 \mathrm{~mm}$; and bit widths range from $32.1-75.0 \mathrm{~mm}$.

\section{Lithic Debris}

The small amount of lithic debris in the Pace McDonald collections (Table 10) indicate that the knapping of stone tools took place at the site, but was not apparently a common activity. Both local $(45 \%)$ and non-local $(55 \%)$ raw materials are represented in the lithic debris.

The non-local lithic debris includes several different colors of chert, including several with a stream-rolled cortex, that likely originated in the Edwards Plateau area of Central Texas, and cobbles and pebbles of this material can be found in stream gravels well to the east of the Plateau, including the Brazos and Trinity River drainages. The local lithic raw matcrials are also available in local stream gravels, most likely in the Neches River valley. The one local hematite flake in the Pace McDonald collection appears to be a ground stone tool manufacture or resharpening piece.

\section{Marine Shell}

A small, pitted/etched, and unmodified marine conch shell is in the collection from the Pace McDonald site, but its provenience within the site is unknown. The conch is $73.3 \mathrm{~mm}$ in length and 49.0 $\mathrm{mm}$ in width.

\section{Animal Bone}

There are five unidentifiable pieces of animal bone in the collections. One of these has been burned.

\section{SUMMARY AND CONCLUSIONS}

The Pace McDonald site (4IAN51) is a prehistoric Caddo mound center in the upper Neches River basin of East Texas; it also was occupied during the Archaic and Woodland periods. Its temporal and cultural relationships to other important mound centers in the region (Figure 5) is poorly known, however, primarily because of limited archaeological investigations and analytical studies over the years. This analysis of the artifacts in the collections of the

Table 10. Lithic Debris.

\begin{tabular}{lccc}
\hline Raw Material & Cortical & Non-Cortical & N \\
\hline Non-local chert & - & 1 & 1 \\
dark gray chert & 1 & 1 & 2 \\
brownish-gray chert & - & 1 & 1 \\
gray chert & 1 & - & 1 \\
grayish-brown chert & 1 & - & 1 \\
brown-black chert & & & 1 \\
Local lithic raw materials & - & 1 & 3 \\
Hematite & 2 & 1 & 1 \\
Quartzite & - & 6 & 11 \\
Petrified wood & 5 & & \\
\hline Totals & & 1 & \\
\hline
\end{tabular}




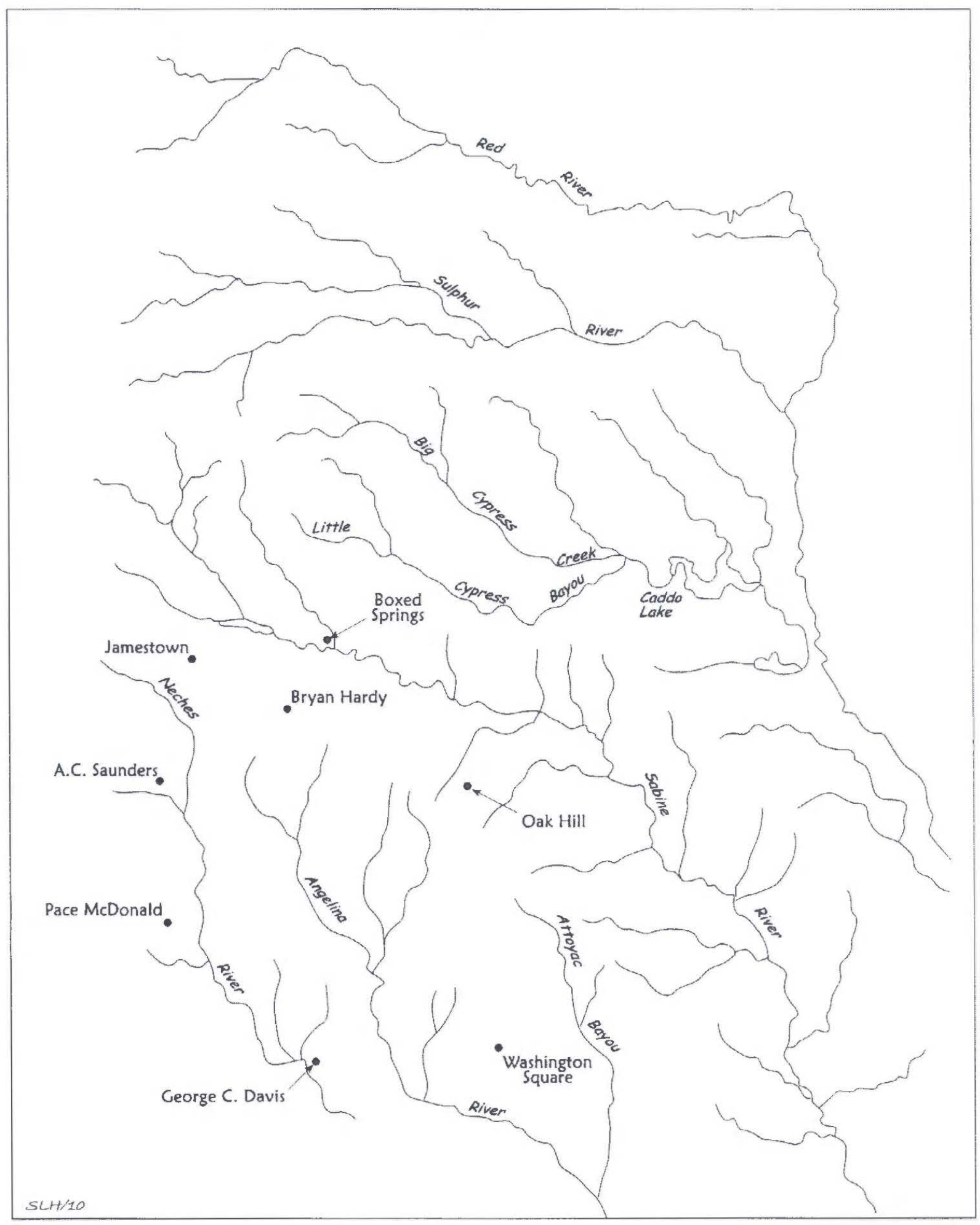

Figure 5. Known Caddo earthen mound sites in the area around the Pace McDonald site. 
Texas Archeological Research Laboratory at The University of Texas at Austin represents the first step in a likely long-term effort to learn more about the nature of the Caddo occupation at this mound center.

What is known about the prehistoric Caddo occupation of the Pace McDonald site is that the site is on an upland landform overlooking Mound Prairic Creck, a tributary to the Neches River, has evidence of a settlement that covers at least 11 acres, and two earthen mounds were constructed there by the Caddo. Both mounds appear to have been built to cover special purpose structures where significant deposits of ash was accumulated, similar to the main mound at the nearby A. C. Saunders site (see Jackson 1936) (see Figure 5) or the ash temple (albeit, without a covering mound) at the Crenshaw site (Schambach 1996).

There also is a reasonably large sample of ceramic and lithic artifacts from the site that have been collected over the years, mainly from Jackson's 1933 excavations in the two mounds and a surface collection, and various surface collections gathered between 1978 and ca. 1985. With respect to the prehistoric Caddo component, the material culture remains that can be associated with it include: (I) a significant percentage of plain ware vessel sherds (mainly grog-tempered), primarily incised, punctated, and incised-punctated utility wares, and both engraved (i.e., geometric elements, significant proportion of hatched and cross-elements, mainly triangles, and carinated bowls and bottles) and (many) red-slipped fine wares; (2) an L-shaped elbow pipe, a 14th century ceramic innovation; and (3) Alba and Perdiz arrow points and a few expedient flake tools.

Temporally, the overall impression obtained from the examination of the decorated sherds, the ceramic pipe, and arrow points is that the Pace McDonald site was first occupied sometime before the 13th century A.D.-based on the predominance of Alba arrow points and some of the decorated utility wares - contemporaneous with some part of the lengthy Caddo occupation at the George C. Davis site (Story 2000). Without radiocarbon dates from the site, it is difficult to establish the early beginnings of this occupation with any precision, largely because the apparently lengthy use (ca. A.D. 850-1300) of many kinds of distinctive Alto phase or Early Caddo ceramic and lithic artilacts, as well as the inability to identify temporal varieties of these artifacts that have more discrete temporal periods of use.

The apparent popularity of red-slipped pottery at the Pace McDonald site is consistent with a Caddo occupation during the 13 th and 14 th centuries A.D., which was when a tradition of manufacturing redslipped carinated bowls and bottles was established across much of the western part of East Texas. At the Middle Caddo period Jamestown Mound site (4ISM54), for example, more than $26 \%$ of the decorated sherds $(n=84)$ are from red-slipped vesscls, including one Maxey Noded Redware bottle sherd (Perttula and Walker 2008:7).

The end of the Caddo occupation at the Pace McDonald site can be more precisely established as ca. A.D. 1350 to A.D. 1400 , based on the presence of the early L-shaped elbow pipe in the assemblage, and perhaps also by the one red-slipped Redwine mode rim (see Walters 2010). Other indications that the Caddo occupation must have lasted into and through the 14th century include Perdiz arrow points, the brushed and pinched utility ware sherds, and much of the distinctive engraved fine wares found at Pacc McDonald. These fine wares from the site may be part of a Middle Caddo period (ca. A.D. 1200-1400) East Texas style zone or ceramic tradition in the Angelina and Neches river basins, as well as parts of the middle and upper Sabine River basin, at other better known and studied sites such as Washington Square, Oak Hill, Redwine, and Jamestown (see Figure 5). The engraved finc wares at these sites have hatched or cross-hatched curvilinear and vertical ladders or narrow panels, as well as hatched and cross-hatched triangles, pendant triangles, or rectangular panels with engraved triangles (see Rogers and Perttula 2004); in some instances, there are engraved vessels with vertical and triangular pancls filled with concentric circles (Hart and Perttula 2010). A number of the engraved fine ware vessels from these sites, but not yet identified in the assemblage of Pace McDonald fine wares, have horizontal interlocking, slanting, and vertical scrolls-including negative S-shaped scrolls-as their principal motif. There are also rayed circles/ sun elements and the swastika cross-in-circle, but these are absent in the small sample of fine wares in the site collections.

It is interesting that the George C. Davis site may also has a component that dates to the Middle Caddo period, and that has a ceramic assemblage that may be part of this East Texas ceramic tradition, although red-slipped sherds are not at all common in the ceramic assemblage (Stokes and Woodring 1981:222-223). Story (2000:13-14) suggests there are "late Alto phase" ceramics (i.e., dating after ca. A.D. 1200) in certain areas of the site that include 
"brushed utility wares, a hallmark of the Frankston phase, as well as Maddox Engraved, Pease BrushedIncised, and other pottery usually associatcd with the Middle Caddoan Bossier phase." Stokes and Woodring (1981:206) indicate that this collection of ceramics also include those with incised or punctated panels as well as appliqued strips. At the George C. Davis site, interestingly, the Maddox Engraved sherds from "late Alto phase" contexts are described as having narrow bands (either straight or curvilinear) filled with cross-hatched lines (Stokes and Woodring 1981:190-191), very similar to several of the decorative elements in the Pace McDonald fine wares (see Figure $2 \mathrm{e}-\mathrm{g}$ ).

Story (2000:23) examined, some years ago, the Pace McDonald collection at the Texas Archeological Research Laboratory at The University of Texas at Austin, and her comments are apt, as she "found little evidence for either an Alto phase or Frankston phasc connection. The age and affiliation of this, one of the few other mound sites near Davis |George C. Davis], are yet to be established." Thurmond (1978:26), some years before, concluded that the Pace McDonald site was "transitional between the two foci [Alto and Frankston]."

Essentially, what both Story (2000) and Thurmond (1978) are suggesting is that the Pace McDonald Caddo occupation dates prior to the onset of the Late Caddo Frankston phase, which occurred around A.D. 1400 , which is a reasonable suggestion, and began sometime before the end of the Alto phase. If the ca. 450 ycars of the "Alto phase" could be subdivided (and there is not necessarily any good reason to think that they can) into two sequent early and late sub-phases of ca. A.D. 850-1075 and ca. A.D. $1075-1300,1$ think it would be fair to say that the Pace McDonald site-while not an Alto phase component-probably began to be occupicd and used at a time contemporaneous with this hypothetical late subphase (ca. A.D. 1075-1300), and its occupation continued into the 14th century A.D. Temporally speaking then, the Pace McDonald site is best viewed as an Early to Middle Caddo period mound site whose occupation overlapped with that of the longoccupied George C. Davis mound center (most likely the component there associated with the construction of the Mound B platform around ca. A.D. 1200, see Story 1997:65), but apparently continued after the George C. Davis mound site was abandoned in the early A.D. 1300 s. In cultural terms, then, and relying heavily on the character of the decorated ceramic sherds in the assemblage, the Pace McDonald site was an important mound center built by a prehistoric Caddo group that was apparently related to others of sinilar socio-political character in the upper Neches, middle and upper Sabine, and the Angelina River basin (see Figure 5 ). Whether it was a subsidiary or satellite to any other contemporancous Caddo mound centers is not known.

\section{ACKNOWLEDGEMENTS}

I would first like to thank Laura Nightengale at TARL for facilitating this examination of the prehistoric artifact collections from the Pace McDonald site. Jean Hughes of TARL also was of assistance through the copying of relevant Pace McDonald site files at TARL. Thanks also to Mark Walters for providing comments on an early draft of this article.

Sandy Hannum drew the two maps, and Morgan Printing helped with the scanning of the artifact illustrations.

\section{REFERENCES CITED}

Alt, $S$.

1999 Spindle Whorls and Fiber Production at Early Cahokian Settlements. Southeastern Archaeology 18(2):124-134.

Coffee, D. R.

1975 Soil Survey of Anderson County, Texas. United States Department of Agriculture, Soil Conservation Service, in cooperation with the Texas Agricultural Experiment Station.

Diggs Jr., G. M., B. L. Lipscomb, M. D. Reed, and R. J. O'Kennon

2006 Illustrated Flora of East Texas, Volume One: Introduction, Pteridophytes, Gymnosperms, and Monocotyledons. Sida, Botanical Miscellany, No. 26. Botanical Research Institute of Texas, Fort Worth.

Gilmore, K.

1974 Appendix I-Analysis of Pipes. In Archaeological Investigations at Lake Palestine, Texas, by K. M. Anderson, K. Gilmore, O. F. McCormick III, and E. P. Morenon, pp. 192-197. Contributions in Anthropology No. 11. Department of Anthropology. Southern Methodist University, Dallas.

Hart, J. P. and T. K. Perttula

2010 The Washington Square Mound Site and a Southeastern Ceremonial Complex Style Zone among the Caddo of Northeastem Texas. Midcontinental Joumal of Archaeology, in press. 
Hoffman, M. P.

1967 Ceramic Pipe Style Chronology along the Red River Drainage in Southwestern Arkansas. The Arkansas Archeologis/ 8(1):4-14.

Jackson, A. T.

1933 Some Pipes of East Texas. Bulletin of the Texas Archeological and Paleontological Society 5:69-86.

1936 A Perpetual Fire Site. Bulletin of the Texas Archeological and Paleontological Society 8:134-174.

Kleinschmidt, U. K. W.

1982 Review and Analysis of the A. C. Saunders Site, 41AN19. Anderson County. Texas. Master's thesis, Department of Anthropology. The University of Texas at Austin.

Lockhart, J. J.

2007 Prehistoric Caddo of Arkansas: A Multiscalar Examination of Past Cultural Landscapes. Ph.D. dissertation, Department of Environmental Dynamics, University of Arkansas, Fayetteville.

McKinnon, D. P.

2010 Exploring Settlement Patterning at a Premier Caddo Mound Site in the Red River Great Bend Region. Southeastern Archaeology 28(2):248-258.

Newell, H. P. and A. D. Krieger

1949 The George C. Davis Sile, Cherokee County, Texas. Memoirs No. 5. Society for American Archaeology, Menasha, Wisconsin.

Pearce, J. E. and A. T. Jackson

1933 Royal Place or Pace McDonald Place. Large Earth Mound and Ash Mound located on Mound Prairie or Wells Creek, $3 / 4$ Mile N. of S.W. from Old Mound Prairic Village, and 9 Miles N.E. of Palestine, Anderson County, Texas. Tested by Digging a Large Shaft in No. 1 and Trenching and Test Holes in No. 2, September 7 to Seplember 9, 1933. MS on file. Texas Archeological Research Laboratory, The University of Texas at Austin.

Perttula, T. K.

2008a (Editor) Lake Naconiche Archeology, Nacogdoches County, Texas: Results of the Data Recovery Excavations at Five Prehistoric Archeological Sites. 2 Vols. Report of Investigations No. 60. Archeological \& Environmental Consultants, LLC. Austin.

2008b The Ceramic Artifacts from the Lang Pasture Site (41AN38) and the Place of the Site within an Upper Neches River Basin Caddo Ceramic Tradition. In Archeological Investigations at the Lang Pasture Site (4IAN38) in the Upper Neches River Basin of East Texas, assembled and edited by T. K. Pertula and D. B. Kelley, pp. 6-1 to 6-260. MS on file, Coastal Environments, Inc., Baton Rouge and Texas Department of Transportation, Environmental Affairs Division, Austin.
Perttula, T. K. and C. P. Walker

2008 The History of Archaeological Investigations and Geophysical Survey at the Jamestown Mound Site (4/SM54), an Archaeological Conservancy Preserve in Smith County: Texas. Archeological \& Environmental Consultants. LLC and Archaeo-Geophysical Associates. LLC, Austin.

Rogers, R. and T. K. Perttula

2004 The Oak Hill Village (41RK2 14), Rusk Count); Texas. Document No. 030083. PBS\&J. Austin.

Schambach, F. F.

1982 An Outline of Fourche Maline Culture in Southwest Arkansas. In Arkansas Archeology in Revien', edited by N. L. Trubowitz and M. D. Jeter, pp. 132-197. Research Series No. 15. Arkansas Archeological Survey, Fayetteville.

1996 Mounds, Embankments, and Ceremonialism in the Trans-Mississippi South. In Mounds, Embankments, and Ceremenialism in the Midsouth, edited by R. C. Mainfort and R. Walling. pp. 36-43. Research Series No. 46. Arkansas Archeological Survey, Fayetteville.

Shafer. H. J. and M. Walters

2010 The Browning Site (41SM195A) Lithics: Considering Patterns of Identity and Interaction through Lithic Analysis. Bulletin of the Texas Archeological Sociest 81:127-151.

Stokes, J. and J. Woodring

1981 Native-Made Artifacts of Clay. In Archeological Investigations at the George C. Davis Site, Cherokee County, Texas: Summers of 1979 and 1980, edited by D. A. Story, pp. 135-238. Occasional Papers No. 1. Texas Archeological Research Laboratory. The University of Texas at Austin.

Story. D. A.

1990 Cultural History of the Native Americans. In The Archeology and Bioarcheology of the Gulf Coastal Plain, by D. A. Story, J. A. Guy, B. A. Burnett, M. D. Frecman, J. C. Rose, D. G. Steele, B. W. Olive, and K. J. Reinhard, pp. 163-366. 2 Vols, Research Series No. 38. Arkansas Archeological Survey, Fayettevillc.

1997 1968-1970 Archeological Investigations at the George C. Davis Site, Cherokee County, Texas. Bulletin of the Texas Archeological Society 68:I-103.

2000 Introduction. In The George C. Davis Site, Cherokee Counry, Texas, by H. Perry Newell and Alex D. Krieger. pp. 1-31. 2nd Edition. Society for American Archaeology, Washington. D.C.

Suhm, D. A. and E. B. Jelks (editors)

1962 Handbook of Texas Archeology: Type Descriptions. Special Publication No. I, Texas Archeological Society, and Bulletin No. 4, Texas Memorial Museum, Austin. 
Thurmond, J. P.

1978 The Pace Mcloonald Site: A Caddoan Mound Center in Anderson County. Texas. MS on file. Texas Archeolugical Research Laboratory. The Universily of Texas at Austin.

Trubitt, M. B.

2009 Investigating Middle: Archaic at the Jones Mill Site. The Arkansas Archeologist 48:71-84.

Turner, F. S. and T. R. Hester

1999 A Field Guide to Stone Artifacts of Texas Indians. Gulf Publishing and Taylor Trade Publishing, Lanham. Maryland.

Turner, R. I.

2006 Hematite $A x e s$ of Northeast Texas. Bulletin of the Texas Archeological Sirciety 77:1-32.
Walker, C. P.

20099 Landscape Archaeogeophysics: A Study of Magnetometer Surveys from Etowah (9I3W]). The (ieorge C. Davis Site (4ICL19), and the Hill Farm Sitc (41BW 169). Ph.D. Dissertation. Department of Anthropology, The Iniversity of Texas at Austin.

Walker, C. P. and T. K. Pertula

2008 Geophysical Investigations on Caddo Sites in East Texas and Surrounding States. Bulletin of the Texas Archeological Socies 79:159-176.

Walters, M., with contributions by T. Middlebrook and T. K. Perttulit

2010 Redwine or Pie-Crust Mode Forms in East Texals Caddo Ceramics and Comparisoms with SprocketRims of Southwest Arkansas. Caddo Archeology Journal 20:77-128. 